\title{
アジピン酸を共重合したポリエチレン テレフタレートの構造と物性*1
}

\author{
京都工芸瀻維大学瀻維学部 清 造 剛 - 趙 龍 錫 $^{* 2}$
}

\section{STRUCTURE AND PROPERTIES OF POLYETHYLENE TEREPHTHALATE COPOLYMERIZED WITH ADIPIC ACID*I}

\author{
By Tsuyoshi Kiyotsukuri and Cho Yong-Suk ${ }^{* 2}$
}

(Faculty of Textile Science, Kyoto University of Industrial Arts and Textile Fibers, Matsugasaki, Sakyo-ku, Kyoto, Japan)

Polyethylene terephthalate copolymers were prepared by substitutions with adipic acid up to $30 \mathrm{~mol} \%$ for the purpose of producing processable polyester fibers easily weight-reduced by alkali.

Melting temperature, glass transition temperature and cold crystallization temperature measured by DTA for the melt-quenched samples decreased with increasing comonomer (adipic acid) content. Density and crystallinity of the hot-pressed films increased with increasing comonomer content. As the comonomer content increased, the rate constant of dissolution of the copolymer measured by hydrolysis in $10 \% \mathrm{NaOH}$ aqueous solution at $80^{\circ} \mathrm{C}$ increased up to the comonomer content of $5 \mathrm{~mol} \%$, decreased up to $10 \mathrm{~mol} \%$, and then increased up to $30 \mathrm{~mol} \%$. This irregular change was also observed for the rate constant of disperse dye absorption measured by dyeing at $80^{\circ} \mathrm{C}$. By the copolymerization, the tensile elongation of the hot-pressed films decreased for the copolymers with the comonomer content of 5 and $10 \mathrm{~mol} \%$ and increased remarkably for that with $30 \mathrm{~mol} \%$ as compared with polyethylene terephthalate. Heat resistance estimated by TG was little affected by the copolymerization.

(Received March 7, 1983)

\section{1. 緒言}

近年ポリエステル繊維の减舅加工が脚光老浴びており， フィラメント織物に広く利用されている゙”。ボエステ ル瀻維在アルカリ水溶液で加水分解する上，䋐維の表面

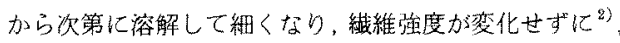
風合いが改善される。とのポリエステル䋐維のアルカリ 加水分解唒しては，橋本 ${ }^{3,4}$ や栗山ら

${ }^{* 1}$ Cの報文在「縮合系共重合体の構诰上物性(第 8 報)， Structure and Properties of Condensation Copolymers (Part 8)」しす万。

*2 現在の所属：曉星女子大学校家政大学衣類学科，韓 国大邱市南区凰德洞 1155

Present address: Department of Textile \& Clothing, Home Economic College, Hyosung Women's University (Bongdukdong, Namgu, Daegu, Korea)
を行っている。

本研究は，縮合系共重合体の構造と物性に関する一連 の研究 ${ }^{6)}$ の環として，ポリエチレンテレフタレートに アジピン酸を共重合するこしによって，芏銷に易加水分 解性の脂肪族エステル結合を摹入し，アルカリ減量加工 の容易なポリエステル䄉維を開発することを目的とした。 そこでまず，共重合体組成とアルカリ加水分解挙動との 関係共，重合体の結晶性や熱的性質，機械的性質，染 色性などし関連させて検傠した結果について報告する。 な㧍，アルカリ加水分解挙動の詳細については，続報 で報告する。

\section{2. 実 験 法}

\section{1 重縮合法}

ジメチルテレフタレートにアジピン酸老所定のモル割 合で混合したもの $20 \mathrm{~g} に ，$ 過剩量のエチレングリコー 


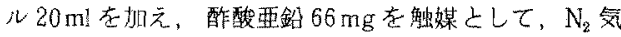
流中で $200 \sim 205^{\circ} \mathrm{C} て ゙ 5 \mathrm{hr}$ 加熱してエステル交換反応さ せた後，250〜 $255^{\circ} \mathrm{C}$ で $1 \mathrm{hr}$ 加熱して過剩のエチレング リコールを留去し， 260〜285 Cで 0.5〜0.2 mmHg の減㞋 下に約 $3 \mathrm{hr}$ 加熱して整縮合させた。

\section{2 フィルム成形法}

粗く砕いた重合物 $450 \mathrm{mg}$ を $5 \mathrm{~cm}$ 角に切り好いた厚さ $100 \mu の ア ル ミ$ 板をスペーサーとして用いてアルミホイ ルの閶比さみ、ホットプレス中で融点よりも20䯩温 で $2 \mathrm{~min}$ 予㪟し，約 $50 \mathrm{~kg} / \mathrm{cm}^{2}$ で加压一除王を 5 回くり 返して脱泡し，最後に約 $200 \mathrm{~kg} / \mathrm{cm}^{2}$ に加王して，承水 中で急冷して製膜した。フィルムに固着して取れ残った アルミホイルは， $35 \% \mathrm{HCl}$ 水溶液中に浸漬して溶解除 シした。このようにして調製したフィルム試料を以下の 測定に供した。

\section{3 溶液粘度测定法}

溶媒化フェール/テトラクロロエタン(60:40wt\%) を用い，1\%濃度で 30 Cでの還元比粘度を，ウベローデ 型粘度計用いて测定した。

\section{4 示差熱分析法}

陚料 $7 \mathrm{mg}$ をアルパンに入れ，融点より $20^{\circ} \mathrm{C}$ 高温で $3 \mathrm{~min}$ 溶融させ， $-55 \sim-60 \mathrm{C}$ に冷却したアセトン中で 急冷して，無定形試料を調製した。この試料を，島津 DT -30 型示差熱分析装置を使用して，昇湜速度 $10 \mathrm{C} /$ $\mathrm{min}$ ，感度 $\pm 50 \mu \mathrm{V}$ で空気中で測定した。

\section{5 密度測定法}

nーヘプタン/四熄化炭素系の密度勾配管を用いて， 30 Cで测定した。

\section{$2.6 X$ 線測定法}

東芝 $\mathrm{ADG}-301$ 型X線回折装㽬を使用し，Niフィル ターした CuK $K_{\alpha}$ 線を用いて, 反射法によってフィルム試 料の下啮強度曲線を作製した。

\section{7 加水分解法}

フィルムを $2 \times 2 \mathrm{~cm}$ に切りとり，10\% $\mathrm{NaOH}$ 水溶液中 で 80 Cで所定時間反応させて減量を求めた。

\section{8 染色法}

フィルムを $80^{\circ} \mathrm{COD1}$ 1,4ージアミノアントラキノン予散 染料の染浴中に投入して，所定時間每にフィルムの一部 を採取して、ーークロロフェノールに溶解し，吸着量を 比色定量した。

\section{9 引張試験法}

フィルムを幅 $3 \mathrm{~mm}$ ，長さ $40 \mathrm{~mm}$ に切りとり，寊津才 ートグラフ IM-100型を使用して，つかみ閒隔 $20 \mathrm{~mm}$, 引張速度 $100 \% / \mathrm{min}$ で测定した。

\subsection{0 熱重量測定}

舅津 DT-30型熱重量測定装犆老使用し，試料量 $5 \mathrm{mg}$ ，
界温速度 $20 \mathrm{C} / \mathrm{min}$ で空気中で剆定した。

\section{3. 結果と考袘}

\section{1 示差熱分析}

DTA曲線を四1亿示す。てのDTA曲線より求めたガ ラ又転移温度 $\left(T_{\mathrm{g}}\right)$, 冷結晶化温度 $\left(T_{\mathrm{cc}}\right)$ 扰上び融点 $\left(T_{\mathrm{m}}\right)$ を，邀元比粘度 $\left(\eta_{\mathrm{sp}} / \mathrm{C}\right)$ とと6に表 1 に示す。Edgar らりはホポリエチレンテレフタレート(PET)にアジピン 酸(AA)を共重合した共重合体の $T_{\mathrm{m}}$ がFlory の融点降

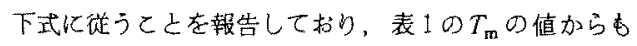
そのととが確認される。な扔，鹿島ら゙)はこれらのポリ エステル共垂合体を長時間熱処理すると， $T_{\mathrm{m}}$ が高温側 にずれて Flory の式があてはまらなくなることを報告し ている。

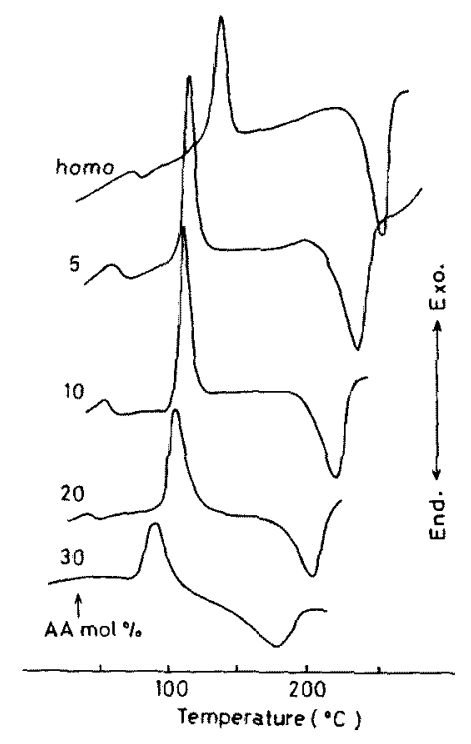

Fig. 1 DTA curves of melt-quenched samples.

Table 1 Reduced viscosity $\left(\eta_{\mathrm{sp}} / C\right)$ of hot-pressed films, and glass transition temperature $\left(T_{\mathrm{B}}\right)$, cold crystallization temperature $\left(T_{\mathrm{cc}}\right)$ and melting temperature $\left(T_{\mathrm{m}}\right)$ measured by DTA for melt-quenched samples.

\begin{tabular}{ccccc}
\hline $\begin{array}{c}\text { Composition } \\
\text { (AAmol \%) }\end{array}$ & $\begin{array}{c}\eta_{\mathrm{sp}} / \mathrm{C} \\
(\mathrm{d} 1 / \mathrm{g})\end{array}$ & $\begin{array}{c}T_{\mathrm{g}} \\
\left({ }^{\mathrm{C}}\right)\end{array}$ & $\begin{array}{c}T_{\mathrm{cc}} \\
\left({ }^{\mathrm{C}}\right)\end{array}$ & $\begin{array}{c}T_{\mathrm{m}} \\
(\mathrm{C})\end{array}$ \\
\hline homo & 0.93 & 78 & 141 & 255 \\
5 & 0.62 & 63 & 117 & 236 \\
10 & 0.61 & 56 & 112 & 222 \\
20 & 0.71 & 43 & 103 & 206 \\
30 & 0.74 & $<30$ & 90 & 182 \\
\hline mol\% of adipic acid (AA) comonomer
\end{tabular}


表 1 で $T_{\mathrm{g}}$ の值はAA 含量の增加とともに低下し，30 モルタでは $T_{\mathrm{g}}$ が室温以下に低下するために，室温から 測定を開始した图1のDTA曲線には $T_{\mathrm{g}}$ に起因する吸熱 が観察されなくなる。Edgar ら゙は， $T_{\mathbf{g}}$ の值が主銷中 の 100 個の脂肪族銷あたりのpーフェニレン結合の数に

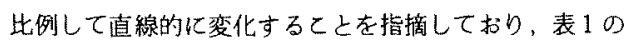
$T_{\mathrm{g}}$ の值加らもそのととが確認される。 $T_{\mathrm{cc}}$ の値す AA含 量の增加とともに低下している。乙机は易屈曲性の脂肪 族銷の導入で結晶化し易くなり，より低温で結晶化が進 行するてとを意味している。

\section{2. 密度およびX線測定}

密度の測定結果を表 2 化示寸。密度は主銧中への脂肪 族銷AAの導入によって增加する傾向が認められる。な お，PETホモについてての密度より算出した結晶化度 は $12.5 \%$ \%った。

Table 2 Density and crystallinity index (CI) of hot-pressed films.

\begin{tabular}{ccc}
\hline $\begin{array}{c}\text { Composition } \\
\text { (AA mol\%) }\end{array}$ & $\begin{array}{c}\text { Density } \\
\left(\mathrm{g} / \mathrm{cm}^{3}\right)\end{array}$ & CI \\
\hline homo & 1.349 & 22 \\
5 & 1.351 & 32 \\
10 & 1.362 & 37 \\
20 & 1.363 & 62 \\
30 & 1.371 & 59 \\
\hline
\end{tabular}

X線回折強度曲線を図2亿示す。PETホモでは無定 形㳊诉い回折曲線を示すが，AA含量が增加するとピー ク强度が增し，結晶化度が增加していくととが推定され る。この曲線より結晶化度を求める場合，結晶ピークと 非晶ピークの分雕による方法では，非晶ピークのとりカ にかなりの任意性が伴い，評価か困難であった。そこで

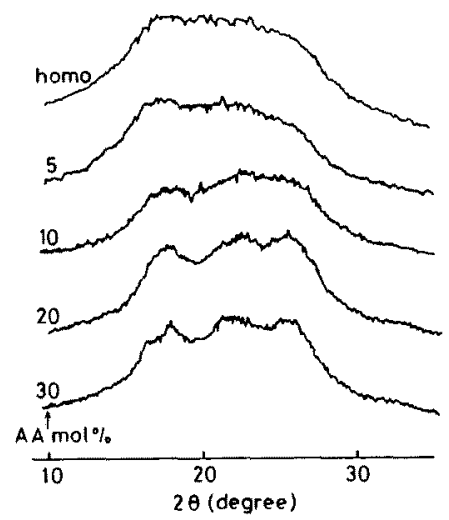

Fig. 2 X-ray diffraction curves of hot-pressed films.
$2 \theta$ が $26^{\circ}$ 付近の (100)ピークの回折强度と $28.6^{\circ}$ の回折 強度の比を用いるBosleyの方法 ${ }^{92}$ 亿上って結晶化度指数 （CI）を算出した。結果表 2 亿併記したCI の值加ら AA含壁の增加によって結晶化度汃增加していることが 確認される。このことは、ホットプレスに祭して急冷し て屯，易届曲性のAA含量の多いつィルムでは結晶化が かなり進行するととを意味しており，図1の $T_{\mathrm{cc}}$ の低下 上関連していると考元られる。

\section{3. 加水分解測定}

$10 \% \mathrm{NaOH}$ 水溶液中で $80^{\circ} \mathrm{C}$ で加水分解䘮行い，フィ ルムの単位表面皘あたりの重量減少量すなわち溶解量 $x / A\left(\mathrm{~g} / \mathrm{m}^{2}\right)$ 学時間 $t(\mathrm{hr})$ に対してプロットして因了に 示す。 $x / A$ と $t$ 之の間代はいず机良好な直線関係が認 められる。

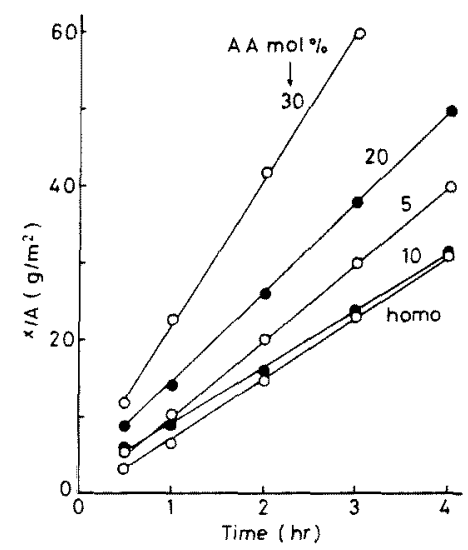

Fig. 3 Weight loss per unit surface area $(x / A)$ versus time of hydrolysis in $10 \% \mathrm{NaOH}$ aqueous solution at $80^{\circ} \mathrm{C}$.

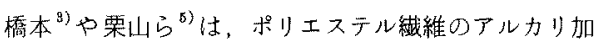
水分解が次式比従うことを示した。

$$
\frac{d x}{d t}=k A
$$

繊䧴試料の場合には，溶解に伴って瀻維が細くなって いくために，表面樍の減少を考慮する必要があるが，本 研究のフィルム試料の場合には表面積が一定に保たれる ので，(1)式をそのまま道用することができる。従って， 图3 の直線の勾配加直接溶解速度定数 $k$ 加得ら扎引。 $k$ 0值を共重合体組成に対してプロットして図 4 亿示 す。AA含量が高い場合には $k$ の值が急激に增玑してお り，易加水分解性の脂肪族エステル結合尊入の寄与がう かがえるが，AA含量が10 モル\%の場合には $k$ 值は PETホモよりむむしろ低下しており，注目されよう。 ての特異な現象の原因として挙げられるのは，前記した 


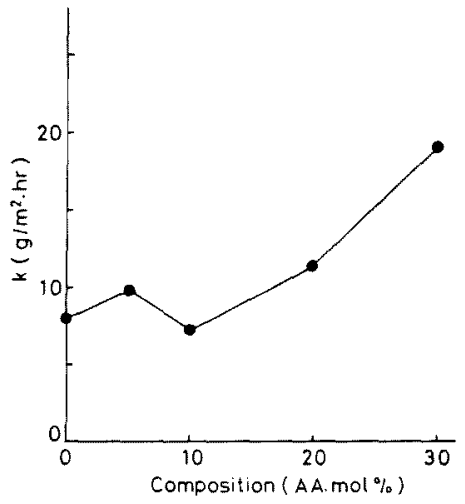

Fig. 4 Rate constant of dissolution $(k)$ of the copolymer by alkali hydrolysis versus copolymer composition.

AA含量の増加に伴う $T_{\mathrm{cc}}$ の低下之結晶化度の增加であ る。橋本 は, PET瀻維を $120^{\circ} \mathrm{C}$ 以上の温度で $5 \mathrm{~min}$ 熱 好理すると溶解速度が增加するととを報告している。一

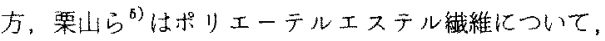
$40 \mathrm{~min} 0$ 熱処理で $160^{\circ} \mathrm{C}$ 以上では $k$ の值が堌加するが， $100 \sim 150 \mathrm{C}$ ○熱処理では逆沉 $k$ が若干減少するととを 笮告している。こてて，熱处理による変化検討してみ た。

図5にAA含量加10モル\%と30モル\%の共重合体に ついて，140 Cで $4 \mathrm{hr}$ 熱処理した試料と末熱処理試料之 を，4\% $\mathrm{NaOH}$ 水溶液中で $80^{\circ} \mathrm{C}$ で加水分解した場合の

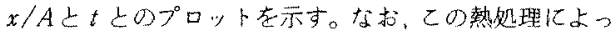
て，密度は10 モル界重合体では 1.379 K、30 モル\% 共重合体では 1.374 に增加した。熱処理によって $0.5 \mathrm{hr}$ 後の溶解量肪减少して求り，フィルムの表面付近に存在

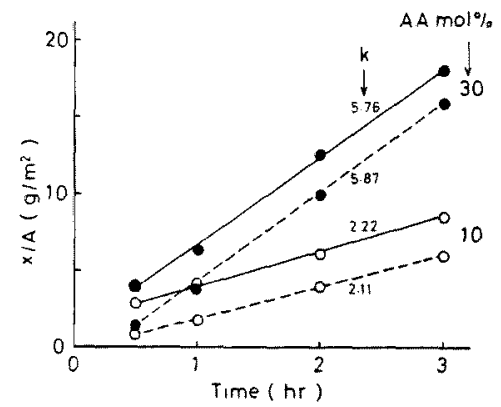

Fig. $5 x / A$ versus time of hydrolysis in $4 \% \mathrm{NaOH}$ aqueous solution at $80^{\circ} \mathrm{C}$ for untreated films $\left(-\right.$ ) and at $140^{\circ} \mathrm{C}$ for $4 \mathrm{hr}$-heattreated films $(---)$.
する易溶解性の成分ないしは構造が熱処理で减少あるい は変化したことが示唆されるが，その後溶解量は值線的 に增加して抢り，熱姏理に上って $k$ の值はあまり影響さ れないと考えられる。

次に，4 hr 加水分解を行った試料について，X線测定 によって求め大結鼠化度指数之密度测定結果を表 3 亿示 す。これらを表 2 と比較すると，加水分解処理化よって 結晶化度加增加していることがわかるが，その增加の程 度はAA含量の少ないもののはうが大きく，その結果拥 水分解物はは類似した結晶化度になっている。なお， PETホモでは密度加ら算出した結晶化度は $35.2 \%$ \% る。

Table 3 Density and crystallinity index (CI) of hot-pressed films hydrolyzed for $4 \mathrm{hrs}$ in $10 \%$ $\mathrm{NaOH}$ aqueous solution at $80^{\circ} \mathrm{C}$.

\begin{tabular}{ccc}
\hline $\begin{array}{c}\text { Composition } \\
\text { (AA mol } \%)\end{array}$ & $\begin{array}{c}\text { Density } \\
\left(\mathrm{g} / \mathrm{cm}^{3}\right)\end{array}$ & $\mathrm{CI}$ \\
\hline homo & 1.375 & 60 \\
5 & 1.376 & 71 \\
10 & 1.373 & 66 \\
20 & 1.372 & 63 \\
30 & 1.373 & 67 \\
\hline
\end{tabular}

以上の結果加ら，図4のkの特異な变化は結晶化度と は瞖接の相関関倸はないと考えられよう。

\section{4 染色性測定}

扣水分解温度之同一の $80^{\circ} \mathrm{C}$ における染色時間 $t$ と单 位表面樍あたりの染料吸着量 $A$ とのプロット在図6 亿示 す。乙の染色速度曲線に，Vickerstaff $\emptyset^{-10}{ }^{10}$ を変形し た次式 ${ }^{11)}$ を適用して求めた染色速度定数 $k$ 亡平衡吸着量

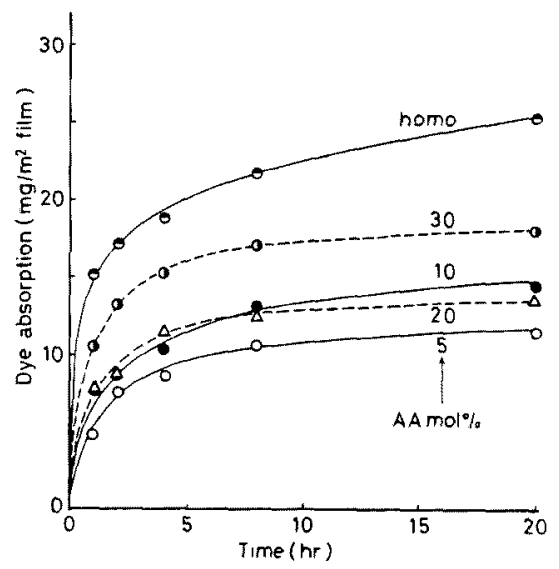

Fig 6 Dye absorption per unit surface area versus time of dyeing with disperse dye at $80^{\circ} \mathrm{C}$. 
Table 4 Rate constant of dye absorption $(k)$ and estimated equilibrium dye absorption $\left(A_{\infty}\right)$ measured by dyeing with disperse dye at $80^{\circ} \mathrm{C}$.

\begin{tabular}{ccc}
\hline $\begin{array}{c}\text { Composition } \\
(\mathrm{AA} \mathrm{mol} \not)\end{array}$ & $\begin{array}{c}k \\
\left(\mathrm{hr}^{-1}\right)\end{array}$ & $\begin{array}{c}A_{\infty} \\
\left(\mathrm{mg} / \mathrm{m}^{2}\right)\end{array}$ \\
\hline homo & 0.302 & 26.2 \\
5 & 0.642 & 12.0 \\
10 & 0.365 & 15.6 \\
20 & 0.521 & 14.4 \\
30 & 0.626 & 18.7 \\
\hline
\end{tabular}

$$
\frac{A}{t}=k A_{\infty}^{2}-k A_{\infty} A
$$

$A_{\infty}$ を表 4 に示す。表 $40 k$ の值は，図 $40 k$ の値と類 做した変化を示しており，注目されよう。従って，加水 分解举動之染色挙動之が共重合体の類似した構造的原因 によって影響さ㣗たととが示唆される。しかし，その構 造的原因については，3.3 で検討したように結晶化度上 は直接には関係していないようであり，非鼠銷の凝集状 態などに関するさらに詳細な檢討が必要と思われる。

\section{5 引張試験}

加水分解前の試料の代表的な $S-S$ 曲線を图 7 亿示す。 ま大加水分解前之加水分解徆のSＳS曲線上り得られた

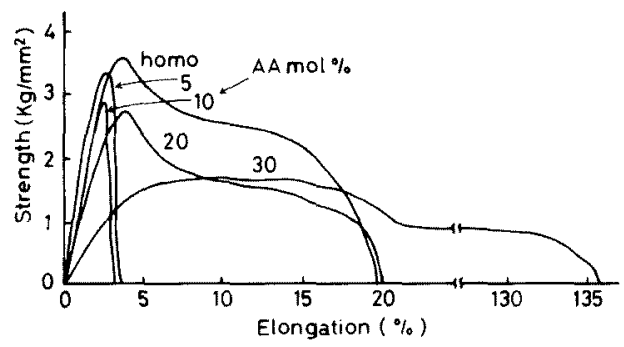

Fig. 7 Typical Strength-elongation curves for hot-pressed films.
主な力学的性質を表 5 に示す。なお，強度は $S-S$ 曲線

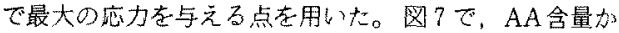
ら5および10モル\%の共重合体に执いては，降伏点近 傍で切断が起こって顕著に伸びにくくなり，AA含量が それ以上になると伸び易くなるととが観察される。ての 現象は，易屈曲性の脂肪族鎖の導入に上る上記した $T_{c c}$ の低下と結晶化度の增加に伴う延伸性の阻害, ならび に易届曲性の脂肪族銷の上り多量の導入《よる分子銷 の易動性の增加に伴う延伸性の增大によって説明され 上う。

加水分解物治度や伸度が低下しているが，加水分

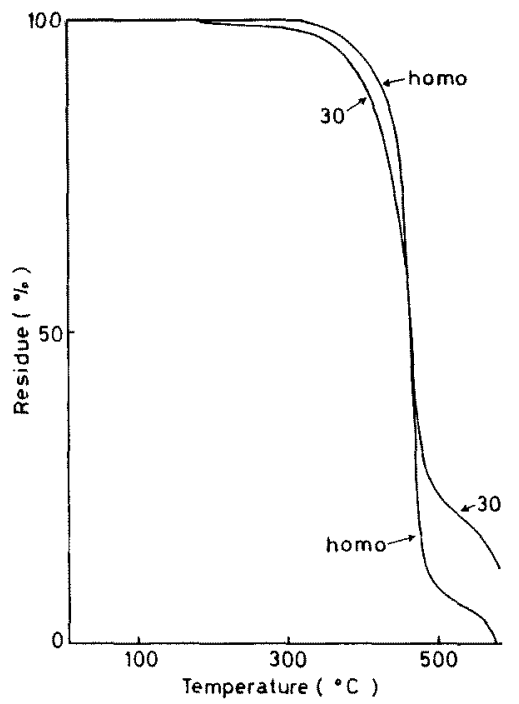

Fig. 8 TG curves for PET homopolymer and copolymer with the comonomer content of $30 \mathrm{~mol} \%$.

Table 5 Tensile properties of hot-pressed films and hydrolyzed films for $2 \mathrm{hr}$ in $10 \% \mathrm{NaOH}$ at $80^{\circ} \mathrm{C}$.

\begin{tabular}{cccccc}
\hline Composition & $\begin{array}{c}\text { Hydrolysis } \\
\text { time } \\
\text { (AAmol } \%)\end{array}$ & $\begin{array}{c}\text { Residual } \\
\text { weight } \\
(\text { hr })\end{array}$ & $\begin{array}{c}\text { Strength } \\
\left(\mathrm{kg} / \mathrm{mm}^{2}\right)\end{array}$ & $\begin{array}{c}\text { Elongation } \\
(\%)\end{array}$ & $\begin{array}{c}\text { Young's } \\
\text { modulus } \\
\left(\mathrm{kg} / \mathrm{mm}^{2}\right)\end{array}$ \\
\hline homo & 0 & 100 & 3.5 & 20 & 159 \\
& 2 & 84 & 3.3 & 6 & 145 \\
5 & 0 & 100 & 3.3 & 3 & 184 \\
& 2 & 80 & 3.1 & 3 & 187 \\
10 & 0 & 100 & 2.9 & 3 & 159 \\
& 2 & 85 & 2.6 & 2 & 168 \\
20 & 0 & 100 & 2.7 & 20 & 110 \\
& 2 & 78 & 1.9 & 2 & 143 \\
30 & 0 & 100 & 1.7 & 136 & 48 \\
& 2 & 62 & 1.4 & 55 & 50 \\
\hline
\end{tabular}


解炕理条件がきびしくなるとこの現象が起こるととは橋 本 ${ }^{3)}$ に上って香指摘さ机ており，扣水分解が不均一に進 行して溶解のはなはだしい部分加ら切断が起こるためと 説明されている。

\section{6 熱重量測定}

AA含量の增加に上って，脂肪族鎖の導入で其重合体 の耐熱性汃影響される可能性がある。そとで TG測定老 行った。測定結果をPETホモさ30モル\%其琶合体につ いて図8 亿示す。その他の其重合体は乙の禹者の曲線の 中間に分布していた。AA拿量加增加すると分解開始温 度は低下し，逆に亳温での残渣星は増加しているが，最 大分解速度孝与える湿度はほぼ问じであり，全体上して 耐熱性にはあまり大きな影響はみられない上いえよう。

讨記：本研究にご援助いただいた京都工芸瀻維大学瀻 維学部内海暢生教授、松本喜代一博士ならびに眰星女子 大学校家政大学衣類学科長成秀光博士に感謝します。

\section{文献}

1）たとえば長谷川元治；染色工業，29，592（1981)

2）たとえば松崎 㤵ら訳；「化学織維亚」，丸善。 p. 14 (1971)

3) 橋本 健；蟣学誌，14，510(1958)

4) 橋本 位; 織学誌, 15,794 (1959)

5）栗山捨三，是松幹雄；繊学誌，16，110（1960）

6) 清造 㴊は加; 瀻学誌，29，T-538(1973)，32， $\mathrm{T}-187$ (1976)，33，T-597(1977), 34, T$435(1978), \quad 35, \mathrm{~T}-13(1979), \mathbf{3 6}, \mathrm{T}-70$ (1980), 37, T-97(1981)

7) O. B. Edgar, R. Hill; J. Polymer Sci., 8, 1 (1952)

8）䴤島俊弘，田藤国臣；高論，35，751（1978）

9) D. E. Bosley; J. Appl. Polymer Sci., 8, 1521 (1964)

10) T. Vickerstaff; J. Soc. Dyers Colourists, 59, 92 (1943)

11) 清造 剛, 藤原 晆; 絨学誌, 32, T-428(1976), 33, $T-291$ (1977) 